\title{
Pain, affect and psychotic illness
}

\author{
H.-J. Möller • P. Falkai
}

Published online: 9 June 2011

(C) The Author(s) 2011. This article is published with open access at Springerlink.com

Dear colleagues,

In order to cope with the increasing amount of interesting papers and due to the fact that Prof. Gattaz (Brazil) and Prof. Deakin (UK) discontinued to be co-editors based on their enormous work load, Hans-Juergen Möller and myself decided to renew and enlarge the editorial board. We are happy that Prof. Takeda (Japan), Prof. Heckers (USA), Prof. McGuire (England), Prof. Leboyer (France), Prof. Arango (Spain), Prof. Maier (Germany) and Prof. Rupprecht (Germany) have accepted our invitation to join the Editorial Board. We will soon decide how we will distribute the scientific fields to the individual members of the Editorial Board in order to improve our review process to maintain and improve the impact of our journal in the field.

The current issue of the European Archives focuses on psychotic disorders. De Hert et al. [1] examined the effects of sertindole and risperidone on metabolic parameters in the short- and long-term treatment of schizophrenia. Segarra et al. [2] connect cognitive performance with smoking in first-episode psychosis. They discuss whether smoking in itself is a self-medication approach in order to improve symptoms like dyscognition. Park et al. [3] take up the discussion of olfactory identification, which is in the

H.-J. Möller

Psychiatry Hospital, Ludwigs-Maximilians-University Munich, Nussbaumstr. 7, 80336 Munich, Germany

P. Falkai $(\square)$

Department of Psychiatry and Psychotherapy,

University of Göttingen, Von-Siebold-Str. 5,

37075 Göttingen, Germany

e-mail: pfalkai@gwdg.de literature for schizophrenia for sometime but examining the specificity of this funding.

Transcranial magnetic stimulation in the treatment of depression has received much attention from clinicians but recently less support in the literature. The paper by Langguth et al. [4] gives a good account of the usefulness of this method in the treatment of depression under naturalistic conditions.

Disturbed pain modulation in psychiatric disorders has been underestimated for long time. Especially in somatoform disorders, this is changing recently. The paper by Klug et al. [5] focuses on the issue of dysfunctional pain modulation in somatoform pain disorder patients.

Affective disorders are closely connected to the functioning of the immune system. Along these lines, Puustinen et al. [6] examines the association between psychological distress and C-reactive protein levels in the blood.

Predicting psychiatric disorders in the offspring is currently discussed intensively. Steinlechner et al. [7] examines this issue from the other side by asking the question whether "Restless legs syndrome" is a possible predictor of psychiatric disorders in parents of children with ADHD. Predicting outcome of severe alcohol-related problems is the basis of a 20-year prospective epidemiological community study by Fichter et al. [8]. These are important data as the majority of our patients will suffer from psychiatric comorbidities for a substantial proportion of their life time.

We hope that you will like the mix of papers relating to main topics in our field and enjoy reading this issue of the European Archives.

Open Access This article is distributed under the terms of the Creative Commons Attribution Noncommercial License which permits any noncommercial use, distribution, and reproduction in any medium, provided the original author(s) and source are credited. 


\section{References}

1. De Hert M, Mittoux A, He Y, Peuskens J (2011) Metabolic parameters in the short- and long-term treatment of schizophrenia with sertindole or risperidone. Eur Arch Psychiatr Clin Neurosci. doi:10.1007/s00406-010-0142-x

2. Segarra R, Zabala A, Eguíluz JI, Ojeda N, Elizagarate E, Sánchez P, Ballesteros J, Gutiérrez M (2011) Cognitive performance and smoking in first-episode psychosis: the self-medication hypothesis. Eur Arch Psychiatry Clin Neurosci. doi:10.1007/s00406-0100146-6

3. Cumming AG, Matthews NL, Park S (2011) Olfactory identification and preference in bipolar disorder and schizophrenia. Eur Arch Psychiatry Clin Neurosci. doi:10.1007/s00406-010-0145-7

4. Frank E, Eichhammer P, Burger J, Zowe M, Landgrebe M, Hajak G, Langguth B (2011) Transcranial magnetic stimulation for the treatment of depression: feasibility and results under naturalistic conditions: a retrospective analysis. Eur Arch Psychiatry Clin Neurosci. doi:10.1007/s00406-010-0137-7
5. Klug S, Anderer P, Saletu-Zyhlarz G, Freidl M, Saletu B et al. (2011) Dysfunctional pain modulation in somatoform pain disorder patients. Eur Arch Psychiatry Clin Neurosci. doi:10.1007/ s00406-010-0148-4

6. Puustinen PJ, Hannu Koponen, Hannu Kautiainen, Pekka Mäntyselkä, Mauno Vanhala (2011) Psychological distress and C-reactive protein: do health behaviours and pathophysiological factors modify the association? Eur Arch Psychiatry Clin Neurosci. doi:10.1007/s00406-010-0134-x

7. Steinlechner S, Brüggemann N, Sobottka V, Benthien A, Behn B, Klein C, Schmid G, Lencer R (2011) Restless legs syndrome as a possible predictor for psychiatric disorders in parents of children with ADHD. Eur Arch Psychiatry Clin Neurosci. doi:10.1007/ s00406-010-0140-z

8. Fichter MM, Quadflieg N, Fischer UC (2011) Severity of alcoholrelated problems and mortality: results from a 20-year prospective epidemiological community study. Eur Arch Psychiatry Clin Neurosci. doi:10.1007/s00406-010-0141-y 